\title{
Climatology and trends of summer high temperature days in India during 1969-2013
}

\author{
A K JASWAL ${ }^{1, *}$, P C S RaO ${ }^{1}$ and VIREndra Singh ${ }^{2}$ \\ ${ }^{1}$ India Meteorological Department, Shivajinagar, Pune 411 005, India. \\ ${ }^{2}$ India Meteorological Department, Lodi Road, New Delhi 110 003, India. \\ *Corresponding author. e-mail: jaswal4@gmail.com
}

Based on the daily maximum air temperature data from 176 stations in India from 1969 to 2013, the climatological distribution of the number of days with high temperature (HT) defined as days with maximum temperature higher than $37^{\circ} \mathrm{C}$ during summer season (March-June) are studied. With a focus on the regional variability and long-term trends, the impacts of HT days are examined by dividing the country into six geographical regions (North, West, North-central, East, South-central and South). Although the long-term (1969-2013) climatological numbers of HT days display well-defined spatial patterns, there is clear change in climatological mean and coefficient of variation of HT days in a recent period (1991-2013). The long period trends indicate increase in summer HT days by 3\%, $5 \%$, and $18 \%$ in north, west, and south regions, respectively and decrease by $4 \%$ and $9 \%$ in north-central and east regions respectively. However, spatial variations in HT days exist across different regions in the country. The data analysis shows that 2010 was the warmest summer year and 2013 was the coolest summer year in India. Comparison of spatial distributions of trends in HT days for 1969-1990 and 1991-2013 periods reveal that there is an abrupt increase in the number of HT days over north, west and north-central regions of India probably from mid 1990s. A steep increase in summer HT days in highly populated cities of Mumbai, New Delhi, Chennai, Jaipur, and Visakhapatnam is noticed during the recent period of 19912013. The summer HT days over southern India indicate significant positive correlation with Nino 3.4 index for three months' running mean (December-January-February, January-March, February-April, March-May and April-June).

\section{Introduction}

It is now very likely that human influence has contributed to observed global scale changes in the frequency and intensity of daily temperature extremes since the mid-20th century and it is likely that human influence has more than doubled the probability of occurrence of heat waves in some locations (IPCC 2013). Global warming has become one of the most challenging issues facing humanity with wide ranging consequences to ecology and human beings all around the world. Compared to 19862005, the global mean surface temperature change for the period 2016-2035 will likely be in the range of $0.3^{\circ}-0.7^{\circ} \mathrm{C}$ (IPCC 2013). A leading manifestation of this is rise in temperatures, which have widespread impacts on different components of the earth-atmosphere system as the change in the temperature extremes is highly associated with the change in mean temperature.

Variability of climate is well demonstrated by extreme climatic events. However, variations and trends in extreme climate events are more sensitive to climate change than are the mean values and so have received much attention. Many studies have documented extreme climatic events (Easterling et al. 1997;

Keywords. Extreme temperature; high temperature days; trend; mega cities; Nino 3.4. 
Gaffen and Ross 1998; Karl and Easterling 1999; Easterling et al. 2000; Frich et al. 2002; Zhai and Pan 2003; Aguilar et al. 2005; Alexander et al. 2006; Qian and Qin 2006; New et al. 2006; Klein Tank et al. 2006; Bartolini et al. 2008; Wei and Chen 2009; You et al. 2008). Frich et al. (2002) and Alexander et al. (2006) analyzed global changes in daily climate extremes, concluding that there have been significant warming throughout the 20th century, and that temperature differences have been particularly pronounced in the most recent periods. Temperature extremes have also been studied in many regions of the world (Zhang et al. 2000; Manton et al. 2001; Peterson et al. 2002; Aguilar et al. 2005; Griffiths et al. 2005; Vincent et al. 2005; Zhang et al. 2005; Klein Tank et al. 2006). These studies have shown that significant widespread changes in temperature extremes are associated with warming. Using Chinese station datasets from 1951-1999, Zhai and Pan (2003) detected a slightly decreasing trend in the number of hot days (daily maximum temperature over $35^{\circ} \mathrm{C}$ ) in China. Also a jump-like acceleration in the number of days with maximum temperature more than $35^{\circ} \mathrm{C}$ since mid-1990s in south, east, north and northwest China is reported by Wei and Chen (2009).

India hosts a variety of climates and is mainly divided into four major climatic zones. These are alpine (Himalayan region), subtropical (northern and peninsular regions), tropical (wet monsoon and dry regions) and arid (western region including Rajasthan). The nation's climate is strongly influenced by the Himalayas and the Thar Desert. The coastal regions of the country are warmer throughout the year with very less variation in temperatures. In India, temperatures start to increase all over the country from March and by April, the interior parts of the peninsula have daily temperatures above $35^{\circ} \mathrm{C}$. Central India becomes hot with daytime maximum temperatures reaching above $40^{\circ} \mathrm{C}$ at many locations. The daily maximum temperatures rise sharply in May with many places in the north and northwest regions of the country reporting temperatures exceeding $45^{\circ} \mathrm{C}$. After the intense heat of the summer months, with the onset of southwest monsoon in June, the daytime temperatures start falling in many parts of the country.

Most of the temperature trend studies in India have focussed on the analysis of mean maximum and minimum temperatures (e.g., Hingane et al. 1985; Srivastava et al. 1992; Rupa Kumar et al. 1994; Arora et al. 2005; Kothawale and Rupa Kumar 2005; Dash et al. 2007; Pal and Al-Tabbaa 2010). In general, they have found increasing trends in both maximum and minimum temperatures over India. Also a strong interannual link between mean temperatures of India and sea surface temperatures of eastern Pacific and Indian Ocean have been found by Kothawale et al. (2010a), who have concluded that El Nino Southern Ocean (ENSO) phenomenon is impacting Indian temperatures significantly. However, very few studies have examined climatology of hot days and trends over India. Some of the studies have investigated extreme maximum temperature and case studies of heat wave spells over some regions as well as over the entire country (Natarajan 1964; Raghavan 1966; Subbaramayya and Surya Rao 1976; Chaudhury et al. 2000; De 2001; Pai et al. 2004, 2013; De et al. 2005; Ray et al. 2013). One of the earliest studies about summer heat waves over India during 1911-1961 by Raghavan (1966) found maximum number of heat waves occurring over east Uttar Pradesh followed by Punjab, east Madhya Pradesh, and Saurashtra and Kutch regions in Gujarat. Chaudhury et al. (2000) have concluded that the impact of heat waves over Bihar, Punjab, and parts of Maharashtra is more. Analyzing 100 years temperature records in India, Sinha Ray and De (2003) have found increasing trend in extreme maximum and minimum temperatures in the south and a decreasing trend in the north. Kothawale and Rupa Kumar (2005) studied the temperature extremes in India for the period 1970-2002 and noted that the number of hot days are highest over central parts of India. Rao et al. (2005) have reported that $80 \%$ stations in peninsular India and $40 \%$ stations in northern India showed increasing trend in the days with extreme maximum temperature during 1971-2000. Kothawale et al. (2010b) have found widespread increasing trend in the frequency of occurrence of hot days in pre-monsoon season. Revadekar et al. (2012) have found widespread warming with increase in intensity of maximum temperature during 1970-2003. Ray et al. (2013) have found significant increase in heat wave and severe heat wave in the last decade (2001-2010) as compared to the last two decades (1981-2000) over Gujarat. Pai et al. (2013) have found significant long term increasing trends in heat wave days over India during 19612010.

Human core body temperature is around $37^{\circ} \mathrm{C}$ irrespective of temperature of the surroundings or the activity level of the individual. If the core temperature goes up, the body loses heat to bring it down again. If the core temperature goes down the body will conserve and even generate heat to bring it up again. Considering the serious effects on human health and public concerns when the daily maximum temperature exceeds the human core body temperature, we have used the criterion of daily maximum temperature above $37^{\circ} \mathrm{C}$ in characterising high temperature days in this study. An attempt has been made to document climatology and variability of high temperature days and 
their long-term trends during 1969-2013 based on daily maximum temperature data of 176 surface meteorological stations well distributed over the country.

\section{Data and methodology}

There are usually two criteria to define high temperature days (DeGaetano and Allen 2002; Yan et al. 2002; Zhai and Pan 2003; Wei and Chen 2009). One uses temperature percentiles (such as $90 \%$ or $95 \%$ or $98 \%$, etc.) and the other uses absolute temperature values (such as $35^{\circ}$ or $37^{\circ}$ or $38^{\circ} \mathrm{C}$, etc.). It is seen that public concern is raised when the daily maximum temperature of a place persistently exceeds $37^{\circ} \mathrm{C}$. We have restricted our study to summer season consisting of March to June months as the high temperature events that can cause large-scale discomfort occur mainly in these months. March and June are transition months for northern (winter to summer) and southern parts (summer to monsoon) of India respectively. The main dry and hot months with mainly clear sky conditions are therefore April to June in northern India and March to May in southern India. The
Sun is also on its northward movement reaching its northern-most position in the third week of June. With high temperature days defined here as days having daily maximum temperature above $37^{\circ} \mathrm{C}$, stations in the mountainous northern parts and some coastal stations where this criterion is hardly met were also omitted. The exclusion of high elevation Himalayan region in north and some coastal stations particularly along the west coast of India from analysis of summer high temperature days does not mean that these regions are free from the effects of increase in temperature.

The data used in this study are the daily surface maximum temperatures obtained from the database of India Meteorological Department (IMD), National Data Centre (NDC) located at Pune, where all climatological data of India are processed, quality checked, and archived. Since daily values of maximum temperature are available from 1969 only, the period of study is restricted to 1969-2013. Initially we had selected 228 surface meteorological stations from IMD's network, which have long data series of daily maximum temperature. First we checked the availability of daily maximum temperature values for each year and stations with too many continuous missing values

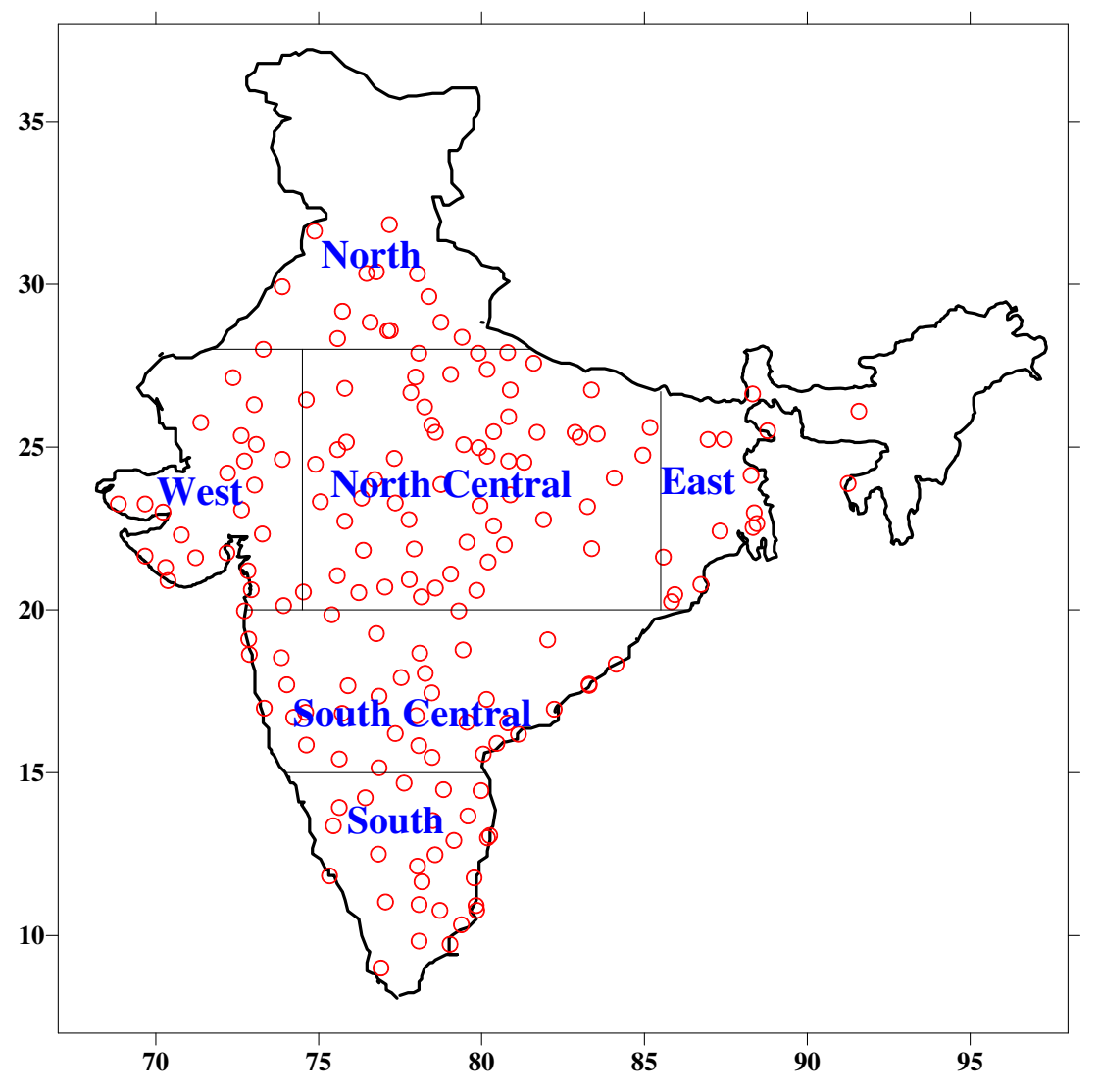

Figure 1. Locations of 176 stations used in high temperature (daily Max $>37^{\circ} \mathrm{C}$ ) days study for India for the period 1969 2013. Six selected regions used in this study are north (stations north of $28^{\circ} \mathrm{N}$ ), west (stations west of $74.5^{\circ} \mathrm{E}$ and bound by $20^{\circ}-28^{\circ} \mathrm{N}$ ), north-central (stations bound by $20^{\circ}-28^{\circ} \mathrm{N}, 74.5^{\circ}-85.5^{\circ} \mathrm{E}$ ), east (stations east of $85.5^{\circ} \mathrm{E}$ ), south-central (stations bound by $15^{\circ}-20^{\circ} \mathrm{N}$ ) and south (stations south of $15^{\circ} \mathrm{N}$ ). 
were dropped from the selected data. Even though data in NDC is thoroughly scrutinized and quality checked before archival, we have marked as outliers daily maximum temperature values above 3.5 times standard deviation. Such values were manually checked and then only taken to the data analysis. Finally, a dataset belonging to 176 meteorological stations was selected for analysis of high temperature days in India. The geographical coverage of stations utilized in this study is shown in figure 1.

As the high temperature events that can cause heat waves and large-scale discomfort occur mainly in summer season, we have selected daily maximum temperature data for March-June months only. Therefore for each station, a high temperature (HT) day is defined as a day when the daily maximum $>37^{\circ} \mathrm{C}$ during the summer season (March-June). In this way, we have calculated the number of HT days at each station during summer season for each year during 1969-2013. Long-term climatology of summer mean maximum temperature and trends in summer highest temperature during 1969-2013 are shown in figure 2(a and b) respectively. The climatological mean and standard deviation of number of HT days were calculated for all of the selected stations and spatial patterns are shown in figure 3 . Temporal variations in number of stations recording more than 80 HT days in summer season each year are shown in figure 4 . In order to investigate trends in number of HT days, a linear regression was fitted to each time series of the number of HT days by using a least square regression for each station. Two-sided Student's $t$ test was used to check the statistical significance at $95 \%$ level of significance. The linear trends were calculated for long period 1969-2013 as well as two short periods by dividing the data in two halves, viz., 1969-1990 and 1991-2013. The spatial distributions of linear trends of summer HT days over India are shown in figure $5(\mathrm{a}-\mathrm{c})$ where trends significant at $95 \%$ level are circumscribed by an outer circle.

Further, regional variations in number of HT days were examined by dividing the entire country into six regions which are North (north of $28^{\circ} \mathrm{N}$ ), West (west of $74.5^{\circ} \mathrm{E}$ and bound by $20^{\circ}-28^{\circ} \mathrm{N}$ ), North-central (bound by $20^{\circ}-28^{\circ} \mathrm{N}, 74.5^{\circ}-85.5^{\circ} \mathrm{E}$ ), East (east of $85.5^{\circ} \mathrm{E}$ ), South-central (bound by $15^{\circ}-20^{\circ} \mathrm{N}$ ), and South (south of $15^{\circ} \mathrm{N}$ ). Statistics of top five highest long-term mean high temperature (HT) days recorded at stations in each of six regions of India during 1969-2013 are given in table 1 . We have prepared regionally averaged time series of number of summer HT days for 1969-2013 and the temporal evolution of the number of HT days is shown in figure $6(\mathrm{a}-\mathrm{f})$. Linear trends in summer HT days at 25 selected mega cities (cities with million plus population) of India are given
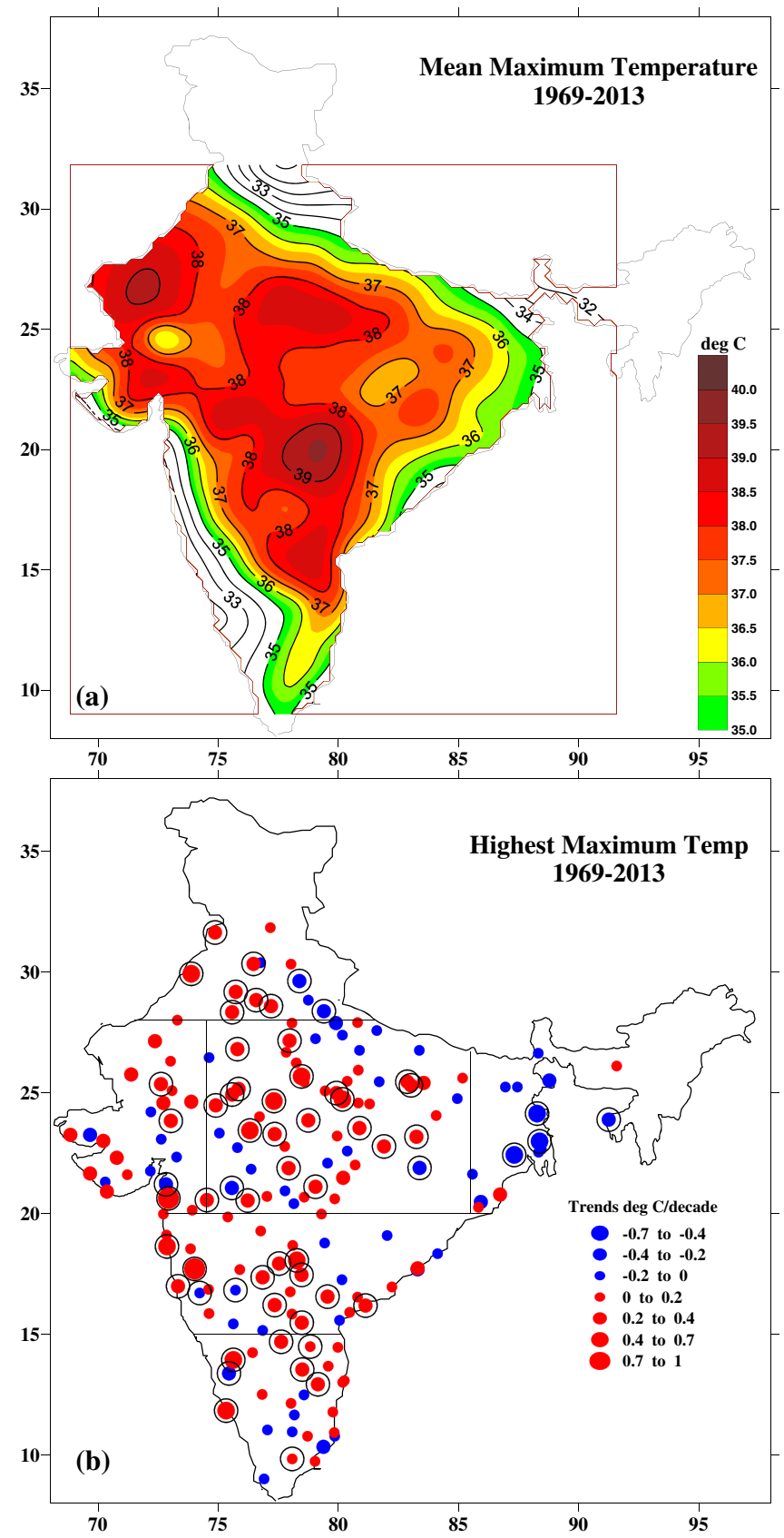

Figure 2. (a) Long-term climatological mean maximum temperature and (b) trends in highest maximum temperature in summer (March-June) during 1969-2013. Trends significant at $95 \%$ level of confidence are shown by an outer circle.

in table 2. As the El Nino Southern Oscillation (ENSO) phenomena influence weather around the world, its impact on summer HT days in India is also examined. The Oceanic Nino Index (ONI) used for identifying El Nino and La Nina years is taken from http://www.cpc.noaa.gov/ for exploring its influence on the intensity of summer HT days in India. We have used 3-month running mean sea surface temperature (SST) anomalies for the Nino 3.4 region $5^{\circ} \mathrm{N}-5^{\circ} \mathrm{S}, 120^{\circ}-170^{\circ} \mathrm{W}$. We have linearly detrended time series of Nino 3.4 anomalies as 


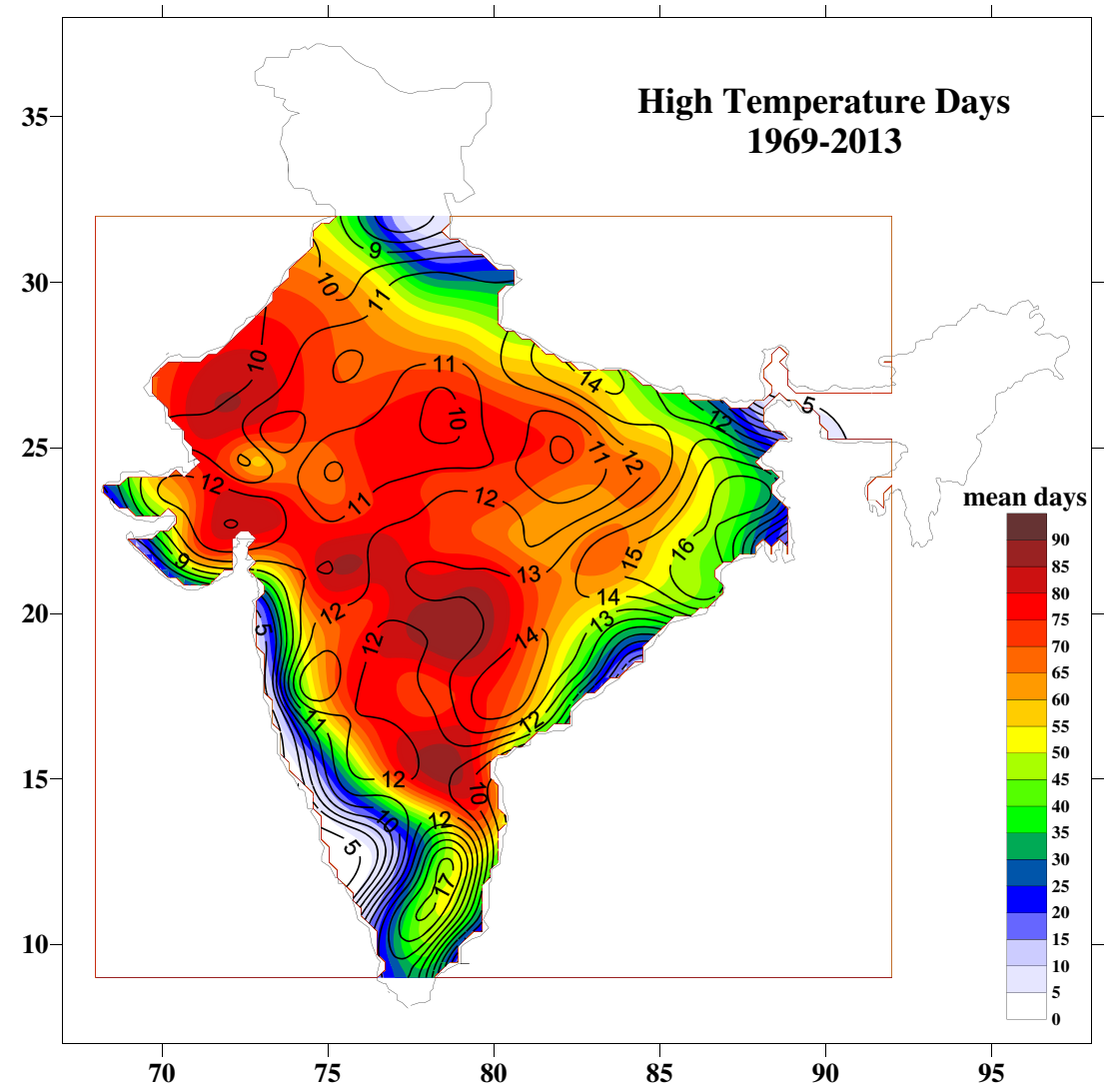

Figure 3. Climatological mean number of days of summer (March-June) high temperature (HT) days and their standard variation for 1969-2013. Contour lines are drawn for standard deviation and mean HT days are shown in the background.

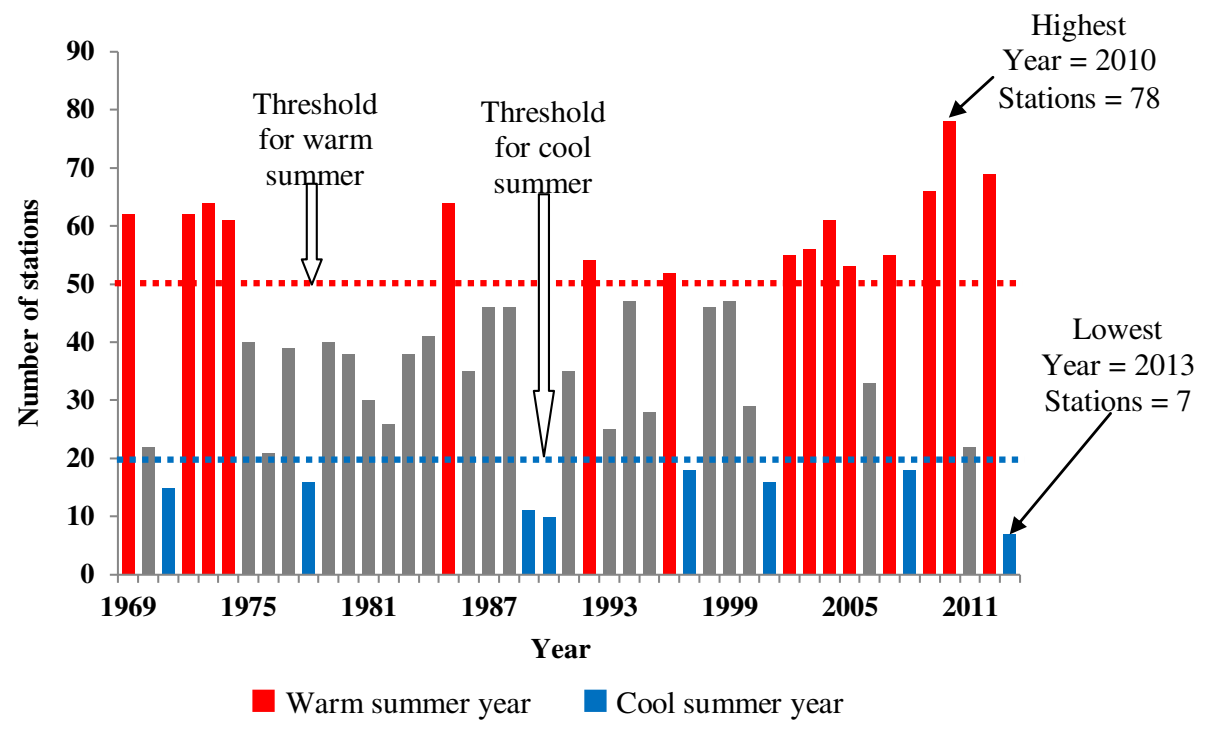

Figure 4. Temporal variations in number of stations having more than 80 high temperature (HT) days in summer months (March to June) in India during the period 1969-2013.

well as HT days anomalies before calculating their correlations. The correlation coefficient between detrended Nino 3.4 anomalies for DJF (December, January and February), JFM (January-March), FMA (February-April), MAM (March-May), AMJ
(April--June) and summer HT days anomalies for six regions of India are given in table 3. A scatter plot between FMA Nino 3.4 SST anomalies and summer HT days anomalies for south-central and south regions of India is shown in figure 7. 

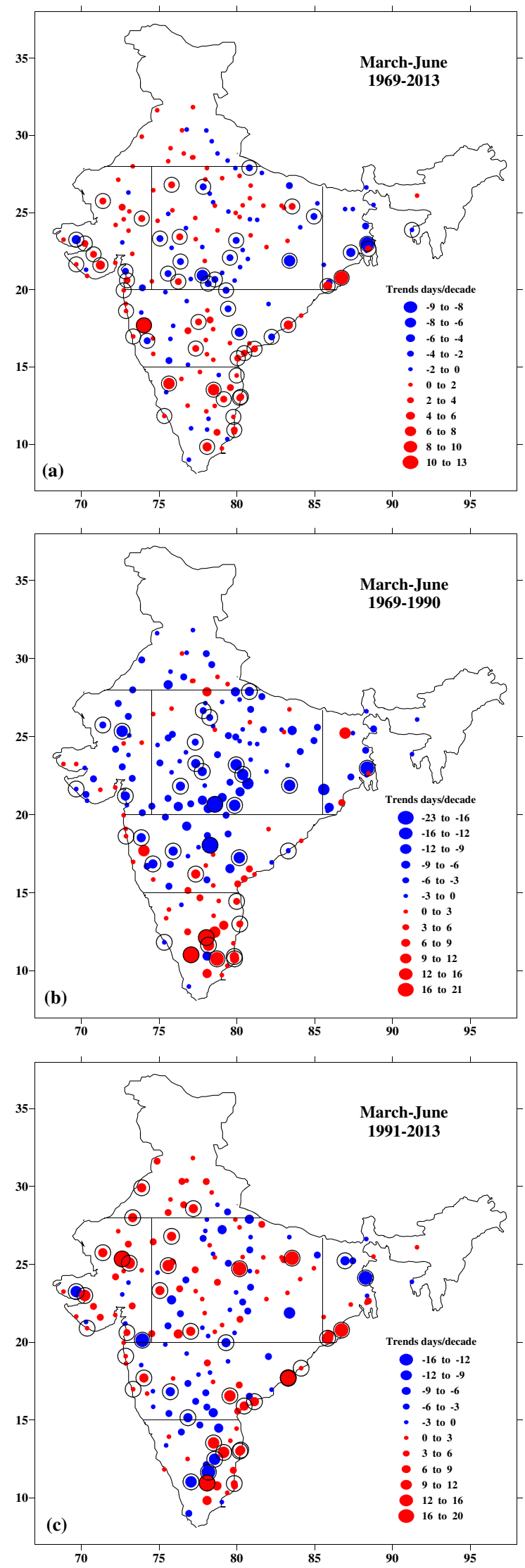

Figure 5. Trend analysis of summer (March-June) high temperature (HT) days for the periods (a) 1969-2013, (b) 1969-1990 and (c) 1991-2013. Trends significant at $95 \%$ level of confidence are shown by an outer circle.

\section{Results}

Summer season in India is characterized by spells of above-normal temperatures, accompanied by hot and dry winds from the west which continuously blow over north and central parts. These strong hot and dry wind mainly originate in the large desert regions of the northwestern Indian subcontinent. This dry and hot wind regime ends in late summer, with the arrival of southwest monsoon.

\subsection{Climatology of HT days for 1969-2013}

Long-term climatology of summer (March-June) mean maximum temperature for 1969-2013 is shown in figure 2(a). The spatial patterns of mean maximum temperature indicate regions of highest mean maximum temperature over northwest, central, and southeast peninsula, where mean temperatures are above $38^{\circ} \mathrm{C}$. Figure 2(b) shows spatial distribution of trends in summer season highest maximum temperature, which are significantly increasing in all regions of India except over east where it is significantly decreasing. Being a country with complex topography, daily maximum temperatures at stations in the mountainous regions of north and northeast India rarely reaches as high as $37^{\circ} \mathrm{C}$ in the summer; therefore, the HT days defined in this study mainly occur over the Indo-Gangetic plains, western, central, eastern, and southern India. Spatial distribution of climatological mean (shaded contours in background) and standard deviations (contour lines in foreground) of the number of summer HT days in India for the period 1969-2013 is shown in figure 3 . The spatial patterns of longterm mean maximum temperature broadly agrees with climatology of HT days suggesting regions of higher summer maximum temperature have higher HT days. On all India level, the station with the most HT days is Jalgaon in north-central region with long period average value of 96.9 days out of total 122 days in summer season (March-June). Other stations with long period average HT days more than 90 days are Cuddapah (95.6 days) in south region, Chandarpur (92 days), and Nandyal (91.9 days) in south-central region. The spatial patterns indicate that regions of higher HT days ( $>70$ out of total 122 days) are located in west, north-central, south-central, and south regions (figure 3). On regional level, stations with highest and lowest long period average HT days are Sri Ganganagar (69.3 days) and Bhuntar (2.8 days) respectively in north; Ahmedabad (88.7 days) and Mount Abu (0.8 days) respectively in west; Jalgaon (96.9 days) and Patna (45.4 days) respectively in north-central; Cuttack (54.5 days) and Agartala and Guwahati (1.5 days each) respectively in east; Chandrapur (92.0 days) and Alibaug (0.8 days) 
Table 1. Statistics of top five highest long-term mean high temperature (HT) days recorded at stations in six selected regions of India during 1969-2013.

\begin{tabular}{|c|c|c|c|c|c|c|c|c|}
\hline \multirow[b]{2}{*}{ Station name } & \multicolumn{2}{|c|}{ HT days } & \multicolumn{2}{|c|}{ Max HT days } & \multicolumn{2}{|c|}{ Min HT days } & \multicolumn{2}{|c|}{ Ever recorded } \\
\hline & $\overline{\text { Mean }}$ & $\overline{\text { Sdev. }}$ & $\overline{\text { Count }}$ & Year & $\overline{\text { Count }}$ & Year & $\operatorname{Max}^{\circ} \mathrm{C}$ & Date \\
\hline \multicolumn{9}{|l|}{ North } \\
\hline Sriganganagar & 69.3 & 10.26 & 96 & 2010 & 44 & 1997 & 50.0 & 14-06-1934 \\
\hline Hissar & 68.3 & 8.84 & 86 & 1999 & 51 & 1983 & 48.8 & 26-05-1998 \\
\hline Pilani & 66.9 & 12.63 & 100 & 1985 & 41 & 1982 & 47.1 & 01-05-2009 \\
\hline New Delhi (Palam) & 64.4 & 10.48 & 84 & 2012 & 38 & 1969 & 48.4 & 26-05-1998 \\
\hline Rohtak & 61.3 & 12.33 & 94 & 2010 & 38 & 1977 & 47.2 & 08-06-1995 \\
\hline \multicolumn{9}{|l|}{ West } \\
\hline Ahmedabad & 88.7 & 12.94 & 111 & 1969 & 54 & 2013 & 47.8 & 27-05-1916 \\
\hline Barmer & 88.6 & 9.93 & 110 & 2010 & 69 & 1982 & 49.9 & 10-05-1995 \\
\hline Phalodi & 84.1 & 9.57 & 102 & 2008 & 60 & 2013 & 49.6 & 07-06-2011 \\
\hline Jodhpur & 83.8 & 10.09 & 108 & 1969 & 58 & 1997 & 47.8 & 07-06-2011 \\
\hline Deesa & 82.8 & 11.84 & 109 & 2010 & 50 & 1997 & 49.4 & 25-05-1932 \\
\hline \multicolumn{9}{|l|}{ North-central } \\
\hline Jalgaon & 96.9 & 9.90 & 115 & 1969 & 71 & 2013 & 48.4 & 28-05-1989 \\
\hline Akola & 89.7 & 11.76 & 118 & 1969 & 59 & 1997 & 47.8 & 22-05-1947 \\
\hline Khandwa & 89.4 & 13.01 & 119 & 1969 & 40 & 2013 & 47.6 & $13-05-1970$ \\
\hline Nagpur & 87.9 & 12.70 & 120 & 1969 & 56 & 1990 & 47.8 & 26-05-1954 \\
\hline Brahmapuri & 86.3 & 14.42 & 116 & 2009 & 56 & 1990,2013 & 47.7 & 27-05-1983 \\
\hline \multicolumn{9}{|l|}{ East } \\
\hline Cuttack & 54.5 & 17.28 & 88 & 1972 & 12 & 1971 & 47.7 & 02-05-1957 \\
\hline Bhubaneshwar & 48.3 & 15.89 & 85 & 2012 & 6 & 1990 & 46.5 & 22-05-1972 \\
\hline Bhagalpur & 46.4 & 15.69 & 75 & 1985 & 9 & 1971 & 46.4 & 28-05-1982 \\
\hline Keonjhargarh & 42.0 & 15.95 & 80 & 1972 & 17 & 2011 & 47.4 & 11-05-1980 \\
\hline Chandbali & 41.7 & 18.52 & 90 & 2010 & 4 & 1971 & 46.7 & 12-06-1942 \\
\hline \multicolumn{9}{|l|}{ South-central } \\
\hline Chandrapur & 92.0 & 11.64 & 114 & 1969 & 63 & 2006 & 49.0 & 02-06-2007 \\
\hline Nandyal & 91.9 & 11.36 & 113 & 1992 & 59 & 1970 & 46.6 & 26-04-2009 \\
\hline Kurnool & 89.1 & 11.40 & 112 & 2012 & 57 & 2008 & 45.6 & 02-06-1998 \\
\hline Ramagundam & 89.0 & 13.03 & 110 & 1969 & 58 & 2008 & 47.3 & 24-05-1984 \\
\hline Nizamabad & 88.0 & 11.86 & 110 & 2009 & 48 & 1990 & 47.3 & 22-05-2005 \\
\hline \multicolumn{9}{|l|}{ South } \\
\hline Cuddapah & 95.6 & 10.24 & 116 & 1992 & 75 & 1999 & 46.1 & $18-05-1906$ \\
\hline Tirupathi (A) & 89.7 & 11.25 & 117 & 2012 & 72 & 1990 & 45.2 & 02-06-2003 \\
\hline Anantapur & 79.3 & 12.65 & 105 & 2003 & 46 & 2008 & 44.1 & 20-05-2001 \\
\hline Nellore & 70.5 & 7.98 & 96 & 2012 & 57 & 2007 & 46.7 & 01-06-1894 \\
\hline Vellore & 66.7 & 15.62 & 100 & 1983 & 35 & 1977 & 45.0 & 31-05-2003 \\
\hline
\end{tabular}

Note: Sdev. is standard deviation of HT days.

respectively in south-central, and Cuddapah (95.6 days) and Ballehonnur (0.9 days) respectively in south.

Standard deviation in summer HT days is highest in Tirupattur (24.46 days) and lowest in Alibaug (1.05 days) as shown in figure 3. Other stations having higher standard deviation are Karur Paramathy, Bagati, and Satara. The pattern of standard deviation in HT days indicates regions of highest variations over the eastern (Gangetic West Bengal and Orissa) and southern (Tamil Nadu) parts of the country. The stations having higher standard deviation (more than 15 days) in the eastern region are Bagati, Chandbali, Cuttack, Berhampore, Keonjhargarh, Bhubaneswar,
Bhagalpur, and Midnapore. Similarly, stations with standard deviation more than 15 days in the southern region are Tirupattur, Karur Paramathy, Salem, Coimbatore, Vellore, Tiruchirapalli, and Madurai. The long-term mean HT days are highest in west, north-central, and south-central regions where variability in HT days are lower indicating regular occurrence of HT days over these regions. However, since the long-term HT days in eastern and southern regions are relatively less compared to western and north-central regions, the higher variability in HT day indicates episodes of severe heat waves in these regions in some extreme hot years. 

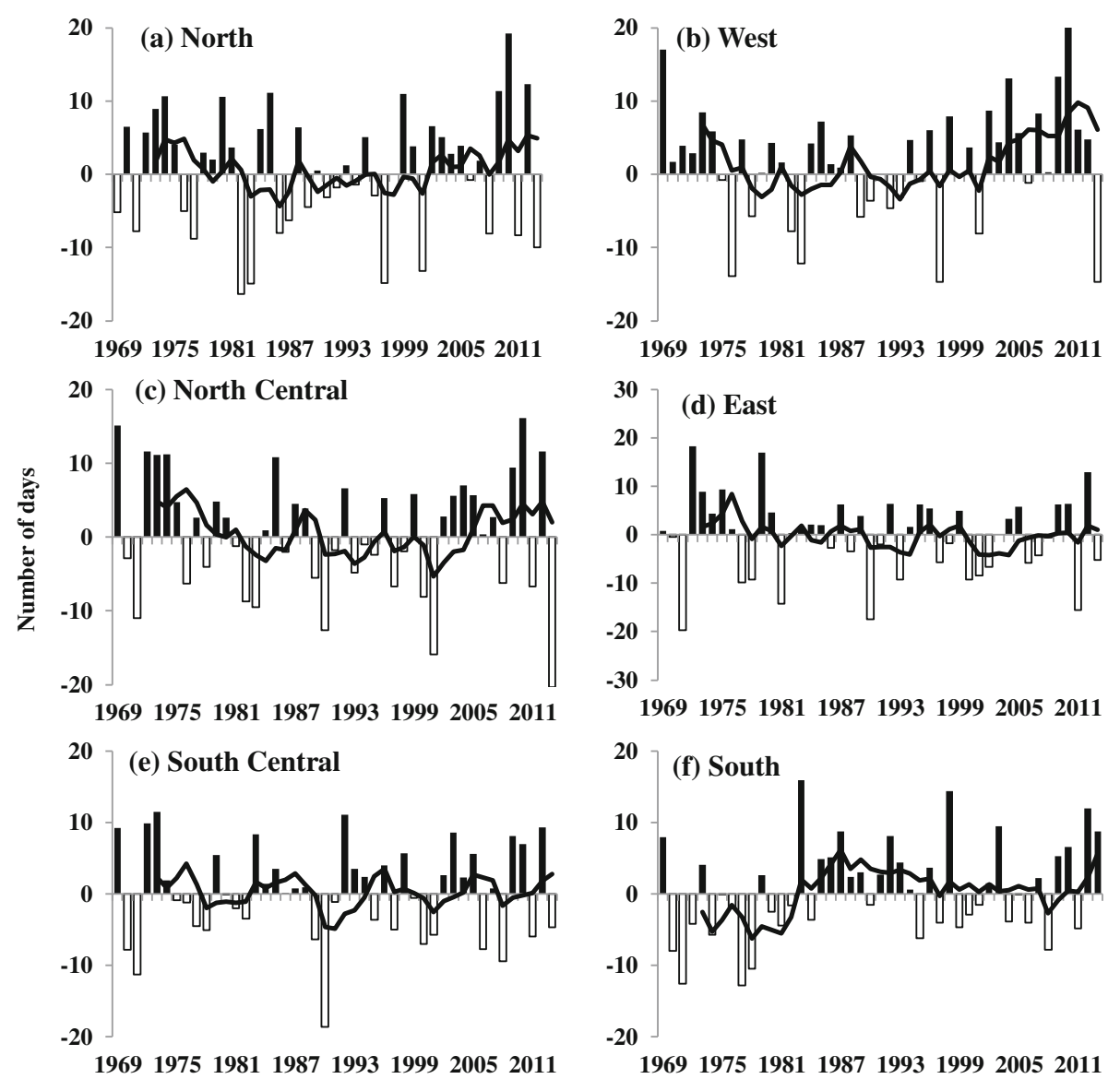

Figure 6. Temporal variations in region level averaged high temperature (HT) days in India for summer season (MarchJune) during 1969-2013. The regions averaged are (a) north (stations north of $28^{\circ} \mathrm{N}$ ), (b) west (stations west of $74.5^{\circ} \mathrm{E}$ and bound by $20^{\circ}-28^{\circ} \mathrm{N}$ ), (c) north-central (stations bound by $20^{\circ}-28^{\circ} \mathrm{N}, 74.5^{\circ}-85.5^{\circ} \mathrm{E}$ ), (d) east (stations east of $85.5^{\circ} \mathrm{E}$ ), (e) south-central (stations bound by $15^{\circ}-20^{\circ} \mathrm{N}$ ) and (f) south (stations south of $15^{\circ} \mathrm{N}$ ). The continuous curves indicate the 5-year moving average. Data series are anomalies in region level averaged HT days from 1971-2000 base period.

\subsection{Highest long-term mean HT days in six selected regions of India}

In order to reveal in detail the regional characteristics of summer HT days in India, we have divided the country into six regions (north, west, northcentral, east, south-central and south) as shown in figure 1. The statistics of top five stations in each region having highest long-term mean HT days in India are given in table 1 . The highest mean HT days 69.3 with standard deviation 10.26 days in north region has occurred in Sriganganagar. But in extreme years, the number of HT days varies from 44 days in 1997 to 100 days in 2010 . In west region, Ahmedabad has the highest longterm mean HT days 88.7 with standard deviation 12.94 days. In Ahmedabad, summer HT days vary between 54 days in 2013 and 111 days in 1969. Jalgaon in north-central region has the highest mean HT days as 96.9 with standard deviation 9.9 days, which also is the highest mean for the country. Summer HT days in Jalgaon vary between 71 days in 2013 and 115 days in 1969 .
Long-term mean HT days in east region are highest in Cuttack (54.5 days) with standard deviation 17.28 days. In extreme years the number of HT days in Cuttack varies between 12 days in 1971 and 88 days in 1972 . Other stations in east region with higher long term mean HT days are Bhubaneswar, Bhagalpur, Keonjhargarh, and Chandbali as given in table 1. Chandrapur has the highest mean HT days 92 with standard deviation 11.64 days in south-central region. The number of HT days vary between 63 days in 2006 and 114 days in 1969 in Chandrapur. Long-term mean HT days in south region are highest in Cuddapah (95.6 days) with standard deviation 10.24 days. However, number of HT days in Cuddapah varied between 75 days in 1999 and 116 days in 1992. It is interesting to note that the highest ever maximum temperature recorded in all six regions is above $45^{\circ} \mathrm{C}$ and the highest daily maximum temperature $50^{\circ} \mathrm{C}$ occurred in Sriganganagar on 14-06-1934 as given in table 1. However, Alwar in east Rajasthan (not included in this study) holds the record for highest maximum temperature of $50.6^{\circ} \mathrm{C}$ for the country, which has occurred on 10-05-1956. 
Table 2. Long-term mean and coefficient of variation (CV) of high temperature (HT) days and trends in summer season (March to June) at 25 mega cities of India. Trends significant at $95 \%$ level are marked as '*'.

Population $\#$ HT days 1969-2013 HT days trends in days/decade

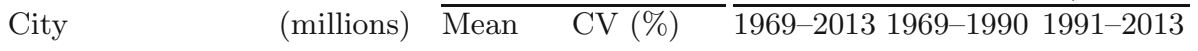

\begin{tabular}{|c|c|c|c|c|c|c|}
\hline Mumbai@ & 18.39 & 4.0 & 77 & 0.44 & 1.20 & $2.16^{*}$ \\
\hline New Delhi ${ }^{@}$ & 16.79 & 60.0 & 17 & 1.87 & 1.43 & $6.30^{*}$ \\
\hline Kolkata $^{@}$ & 14.06 & 19.0 & 57 & $2.73^{*}$ & 1.66 & 5.22 \\
\hline Chennai $^{@}$ & 8.65 & 45.2 & 19 & $2.96^{*}$ & $4.25^{*}$ & $7.96^{*}$ \\
\hline Hyderabad ${ }^{@}$ & 7.67 & 63.7 & 19 & 1.43 & 0.14 & 1.01 \\
\hline Ahmedabad $^{@}$ & 6.36 & 88.7 & 15 & -0.42 & -5.06 & -0.32 \\
\hline Pune & 5.06 & 44.1 & 24 & -0.49 & $-8.25^{*}$ & -1.13 \\
\hline Jaipur@ & 3.05 & 67.9 & 18 & $2.91^{*}$ & 1.80 & $7.73^{*}$ \\
\hline Lucknow@ & 2.90 & 65.7 & 17 & 0.09 & -3.41 & -1.59 \\
\hline Nagpur & 2.50 & 87.9 & 14 & -0.48 & -7.10 & 2.35 \\
\hline Indore & 2.17 & 71.1 & 16 & -0.71 & -2.58 & -6.54 \\
\hline Coimbatore & 2.14 & 21.9 & 77 & -0.67 & $20.60 *$ & $-9.02^{*}$ \\
\hline Patna $^{@}$ & 2.05 & 45.4 & 30 & -1.17 & -5.36 & -4.01 \\
\hline Bhopal $^{@}$ & 1.89 & 71.2 & 16 & 0.50 & $-6.82^{*}$ & 2.07 \\
\hline Baroda & 1.82 & 82.4 & 15 & 1.90 & -3.23 & 5.59 \\
\hline Vishakhapatnam & 1.73 & 22.0 & 61 & $4.59^{*}$ & -1.64 & $18.14^{*}$ \\
\hline Madurai & 1.47 & 63.2 & 24 & $4.57^{*}$ & 8.02 & 6.11 \\
\hline Varanasi & 1.43 & 72.7 & 14 & 1.05 & -0.11 & 1.79 \\
\hline Rajkot & 1.39 & 82.0 & 14 & $2.36^{*}$ & -4.44 & 3.68 \\
\hline Solapur & 1.20 & 84.1 & 13 & -0.13 & $-7.28^{*}$ & 0.99 \\
\hline Aurangabad & 1.19 & 67.4 & 19 & -0.85 & -5.89 & -2.65 \\
\hline Amritsar & 1.18 & 52.3 & 20 & 0.19 & -2.28 & 4.21 \\
\hline Gwalior & 1.12 & 76.9 & 12 & -0.54 & $-5.21^{*}$ & 0.33 \\
\hline Tiruchchirappalli & 1.02 & 64.8 & 24 & 2.67 & $12.22^{*}$ & 7.16 \\
\hline Kota & 1.00 & 79.9 & 13 & 1.45 & -3.13 & 5.27 \\
\hline
\end{tabular}

\# INDIA STATS: Million plus cities in India as per Census 2011 http://pibmumbai. gov.in/

@ State capital cities; New Delhi is also capital of India.

Table 3. Correlation between sea surface temperature (SST) anomalies in Nino 3.4 region $\left(5^{\circ} \mathrm{N}-5^{\circ} \mathrm{S}, 120^{\circ}-170^{\circ} \mathrm{W}\right)$ and summer high temperature (HT) days anomalies over six regions of India during 1969-2013 after removing linear trend. SST anomalies are for December, January, February (DJF), January, February, March (JFM), February, March, April (FMA), March, April, May (MAM) and April, May, June (AMJ). Correlations significant at $95 \%$ level of significance are marked as "*'.

\begin{tabular}{lcccccc}
\hline & \multicolumn{6}{c}{ Coefficient of correlation between Nino 3.4 SST and summer HT days } \\
\cline { 2 - 6 } & North & West & North-central & East & South-central & South \\
\hline DJF & 0.05 & 0.20 & 0.20 & 0.13 & $0.44^{*}$ & $0.49^{*}$ \\
JFM & 0.03 & 0.17 & 0.22 & 0.17 & $0.46^{*}$ & $0.52^{*}$ \\
FMA & -0.02 & 0.12 & 0.20 & 0.20 & $0.47^{*}$ & $0.55^{*}$ \\
MAM & -0.14 & 0.04 & 0.13 & 0.18 & $0.41^{*}$ & $0.51^{*}$ \\
AMJ & $-0.29^{*}$ & -0.07 & 0.05 & 0.14 & $0.31^{*}$ & $0.36^{*}$ \\
\hline
\end{tabular}

\subsection{Temporal variations in summer HT days in six selected regions of India}

Analysis of summer HT days data series for 19692013 reveals temporal variations of extreme hot years at individual stations. In north, Pilani has extreme hot year in 1985 with 100 HT days out of total 122 summer days. Other hot summer years in Pilani are 2004 (91 days) and 2002 (88 days). Similarly, Sriganganagar and Rohtak also experienced maximum HT days 96 and 94, respectively in the year 2010. In west region, Ahmedabad has 


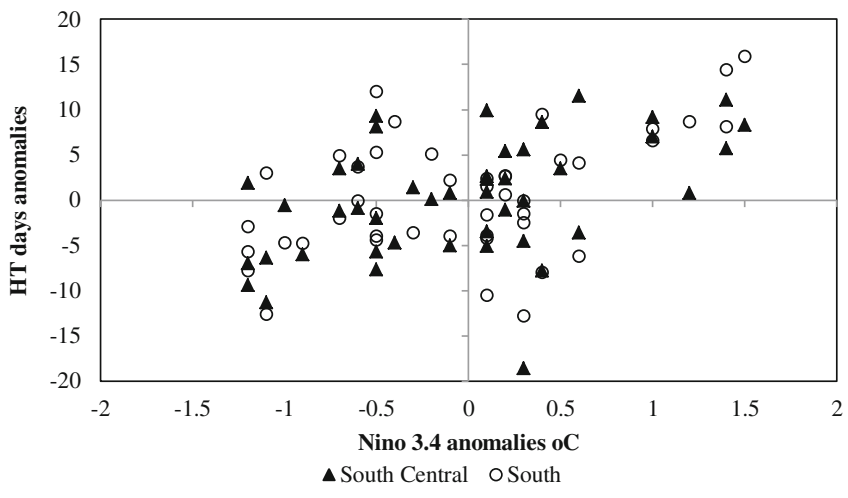

Figure 7. Scatter plot of Nino 3.4 anomalies for FebruaryApril (FMA) and summer high temperature (HT) days anomalies over south-central (SC) and south (S) regions of India during 1969-2013.

111 HT days in 1969, Barmer and Jalore have 110 HT days each in 2010. Some other hot years in Ahmedabad are 1974 (109 days) and 2010 (107 days). North-central region has highest HT days at Wardha in 1969 (121 days) followed by 110 and 105 days in 1974 and 1972 respectively. Hot years in Nagpur are 1969 (120 HT days), 2009 (111 HT days) and 2010 (107 HT days). In east region, the top three stations having highest HT days are Chandbali (90 days in 2010), Cuttack (88 days in 1972) and Bagati (87 days in 1975). South-central region has highest HT days at Rentachintala (119 days in 2012) followed by Chandrapur (114 days in 1969) and Nandyal (113 days in 1992). Some other hot years at Rentachintala are 1972, 1975 (105 HT days each) and 1973 (104 HT days). Chandrapur has 111 HT days in 1974 and 109 HT days in 1972 while Nandyal has 108 HT days in 2003 and 106 HT days in 1987. In south region, top three stations recording extreme hot years during 1969-2013 are Tirupathi (117 HT days in 2012), Cuddapah (116 HT days in 1992) and Tirupattur (106 HT days in 1973). Some of the other hot years recorded in Tirupathi are 1992 and 2009 (109 HT days each). Analysis of HT days shows that the phenomenon of heat spells over India migrates from one region to other in different years.

\subsection{Hot summer years during 1969-2013}

The summer season (March-June) in this study has total 122 days. We have tried to identify warm and cool summer years during the period of study by using the criteria of persistency and spatial coverage of hot days. First we have enumerated the number of stations in each year having more than 80 HT days in summer season at each station during 1969-2013. The temporal variations of number of stations having more than 80 HT days each year is shown in figure 4 . Further those years with more than 50 such type of stations out of total 176 stations are categorized as hot summer years and those years with less than 20 such type of stations are categorized as cool summer years over the country. The data analysis shows that in India, 2010 was the warmest summer year having 78 stations with more than $80 \mathrm{HT}$ days and 2013 was the coolest summer year with just 7 stations with more than 80 HT days (figure 4). Interestingly, 2010 is a strong La Nina year also. Almost all regions of the country experienced heat spells in 2010 with 26 stations recording more than $100 \mathrm{HT}$ days. Also there are total 15 such warm summer years in India during the period of 1969-2013 out of which 8 happened in the last decade $(2010,2012,2009,2004,2003$, 2002, 2007, and 2005 arranged in descending order of intensity). Similarly, there are 8 cool summer years $(2013,1990,1989,1971,2001,1978,2008$, and 1997 arranged in descending order of intensity). Lack of any warm year during 1975-1984 and 8 warm years during 2002-2012 clearly indicates warm summers during the latter period.

\subsection{Trend analysis of summer HT days}

Trends in summer HT days across India for the period 1969-2013 are obtained using linear regression analysis and the trends were tested for significance at $95 \%$ level of confidence. To evaluate changes in summer HT days in recent decades, we have also computed trends for two periods, 1969-1990 and 1991-2013.

\subsubsection{Period 1969-2013}

The spatial patterns of summer HT days trends for 1969-2013 are shown in figure 5(a) where many stations in north-central and east regions of India show a decreasing trend. In north region, New Delhi (Safdarjung) shows non-significant increasing trend $(+1.87$ days per decade) in summer HT days while Najibabad is having nonsignificant decreasing trend (-1.28 days per decade). The highest significant increase in HT days in west region has occurred at Amreli and Bulsar in Gujarat at a rate of +4.8 and +3.7 days per decade respectively while Bhuj has the highest significant decreasing trend ( -4.41 days per decade). In northcentral region, the largest significant decreasing trend occurred at a rate of about -7.1 days per decade and -6.5 days per decade at Raigarh (in Chhattisgarh) and Amraoti (in north Maharashtra), respectively. The largest significant decreasing trend in east region occurred at a rate of about -8.5 days per decade at Bagati, while Chandbali and Bhubaneswar (in Orissa) have strong increasing trends in summer HT days at a rate of +9.9 and 
+4.7 days per decade, respectively. Significantly steep increase in summer HT days has occurred in west, south-central and south regions of India. In south-central region, the largest significant increasing trend occurred at a rate of about +12.3 and +4.6 days per decade at Satara (in western Maharashtra) and Visakhapatnam (in coastal Andhra Pradesh), respectively. South region has largest increase in summer HT days at Shimoga (in Karnataka) and Arogyavaram (in Andhra Pradesh), with trends at a rate of +6.5 and +6.1 days per decade, respectively.

\subsubsection{Periods 1969-1990 and 1991-2013}

Dividing data for 1969-2013 into almost two equal periods, figure 5 (b and $\mathrm{c}$ ) shows spatial patterns of summer HT days trends for 1969-1990 and 1991-2013, respectively. Out of total 176 stations, 116 stations showed decreasing trends during the first period of 1969-1990, only 70 stations have decreasing trends in the second period 1991-2013. The split up of the overall period of study into two halves helps in better understanding of changing patterns of HT days and their distribution across India. It is clear from spatial patterns that the two periods have some contrasting features of magnitude as well as sign of trends in summer HT days. During the first period of 1969-1990, majority of stations in north, west, north-central, east and south-central have decreasing trends as shown in figure $5(\mathrm{~b})$. In each region, stations having largest decreasing trends during the first period are Pilani ( -6.6 days/decade) in north, Jalore $(-11.3$ days/decade) in west, Wardha ( -18.8 days/decade) in north-central, Bagati (-15.9 days/decade) in east and Medak (-22.7 days/decade) in northcentral. Only south region of India has increasing trends in HT days during 1969-1990 where Dharamapuri $(+20.8$ days/decade), Coimbatore (+20.6 days/decade), Tiruchirapalli $(+12.2$ days/ decade) and Tirupattur (+11.5 days/decade) have large significant increasing trends. In contrast to the first period, majority of stations in north, west and north-central regions show increasing trends in summer HT days in the second half period of 1991-2013 as shown in figure 5(c). While overall cooling is seen in the first half, there is general warming in HT days at most of the stations in the latter half. Stations having largest significant increasing trends in HT days during 19912013 are Sriganganagar and New Delhi $(+6.3$ days per decade each) in north, Jalore $(+19.9$ days per decade) in west, Panna (+15.6 days per decade) in north-central, Bhubaneswar $(+10.5$ days per decade) in east, Visakhapatnam (+18.1 days per decade) in south-central and Karur Paramathy $(+19.9$ days per decade) in south regions.

\subsubsection{Mega cities trends}

Rapid urbanization is occurring largely in developing countries where a massive demographic shift has enormous implications in terms of poverty, natural resources, and the environment. Urban artificial covers like concrete, asphalt, etc., substantially modify the energy budget of cities leading to changes in local climatic conditions.

We have examined the behaviour of summer HT days over 25 selected cities with million plus population (mega cities) in India, some of which are also state capitals and the trends are given in table 2 . Among the selected mega cities, Mumbai is highly populated with 18.39 million people while Kota has just 1 million. Out of these 25 mega cities, 17 cities have long-term mean summer HT days on more than $50 \%$ of the total period of summer season (122 days). The long-term mean summer HT days are highest in Ahmedabad (88.7 days) and lowest in Mumbai (4 days). However, among the selected mega cities, summer HT days variability is highest in Mumbai and Coimbatore (77\% each) indicating high probability of sporadic hot years. Summer HT days variability is lowest in Gwalior (12\%) which also has higher long-term mean HT days (76.9) suggesting persistence in warm years. Out of 25 mega cities, 16 show long-term (1969-2013) increasing trends which are significant at Kolkata $(+2.73$ days per decade), Chennai $(+2.96$ days per decade), Jaipur (+2.91 days per decade), Visakhapatnam ( +4.59 days per decade), Madurai $(+4.57$ days per decade), and Rajkot $(+2.36$ days per decade). The comparison of features of trends for two split period of 1969-1990 and 1991-2013 suggest considerable increase in summer HT days in highly populated cities of Mumbai $(+2.16$ days per decade), New Delhi (+6.3 days per decade), Chennai $(+7.96$ days per decade), Jaipur $(+7.73$ days per decade), and Visakhapatnam $(+18.14$ days per decade) during the recent period of 1991-2013. Among the mega cities, the highest rate of change in summer HT days is obtained for Visakhapatnam which has seen discernible warming in 1991-2013 period with change in mean from 18 days (1969$1990)$ to 25 days and highest number of HT days 65 occurring in 2012. A strong cooling trend at the rate of -9.02 per decade is also observed in Coimbatore during the period of 1991-2013 which has seen decrease in mean HT days from 25 days in 1969-1990 to 19 days in 1991-2013.

\subsection{Temporal variation of region level averaged $H T$ days}

Temporal variations in region level averaged HT days in India for summer season (March-June) during 1969-2013 are shown in figure 6. The 
summer HT days have increased by $3 \%, 5 \%$ and $18 \%$ in north, west, and south regions, respectively and decreased by $4 \%$ and $9 \%$ in north-central and east regions, respectively during 1969-2013. Region level average HT days obtained are 51.1, 57.9, 71.9, $27.3,53.2$, and 38.0 in north, west, north-central, east, south-central, and south, respectively during 1969-2013. However, steady increase in HT days is evident over north, west, and north-central regions as shown in figure 6 , where extremely hot summers occurred in the years 2010, 2009, and 2012. While year 2010 is the hottest summer year in north, west, and north-central regions, there is no common year for east, south-central, and south regions which have 1972, 1973, and 1983 respectively as the hottest year indicating regional preferences in hot summer years in India. Other hot years in north are 2012 and 2009, in west 1969 and 2009, in northcentral 1969 and 2012, in east 1979 and 2012, in south-central 1992 and 1972 and in south 1998 and 2012. At region level, the coolest summer years are 1982 in north, 1997 in west, 2013 in north-central, 1971 in east, 1990 in south-central, and 1977 in south. The increase in summer HT days will profoundly affect the economic activities and social life, especially when projected into the future under conditions of continuous global warming.

\subsection{Nino 3.4 index and summer HT days correlation}

A strong interannual link between Indian mean temperatures and sea surface temperature (SST) of eastern Pacific and Indian Ocean was found by Kothawale et al. (2010a). They have concluded that El Nino is impacting surface temperatures in India significantly. We have made an attempt to assess the impact of Nino 3.4 Index on summer HT days for six selected regions of India by calculating the coefficients of correlations. Table 3 gives coefficients of correlation between detrended SST anomalies over Nino 3.4 region $\left(5^{\circ} \mathrm{N}-5^{\circ} \mathrm{S}, 120^{\circ}-\right.$ $170^{\circ} \mathrm{W}$ ) for DJF (December, January, February), JFM (January-March), FMA (February-April), MAM (March-May), and AMJ (April-June) and detrended summer high temperature (HT) days anomalies over six selected regions of India during 1969-2013. The magnitudes of coefficients of correlation are lower (ranging between -0.29 and +0.23 ) for north, west, north-central, and east regions while it is higher (lying between +0.31 and +0.55 ) for south-central and south regions of India. While north region has a significantly negative correlation with AMJ Nino 3.4 index, south-central and south regions have significant positive correlation for DJF, JFM, FMA, MAM, and AMJ. A scatter plot of Nino 3.4 anomalies for FMA and summer HT days anomalies for south-central and south regions (figure 7) suggests higher (lower) HT days in years of strong positive (negative) Nino 3.4 index for FMA. For example, Nino 3.4 index was lowest $(-1.2)$ in 1974, 2000, and 2008 and summer HT days in south-central region were also low (54.8, 45.9 and 43.5 days, respectively). Similarly, the year of highest Nino 3.4 index for FMA $(+1.5$ in 1983) has higher summer HT days in south-central (61.2 days) and south (53.3 days) regions. The Nino 3.4 index was +1.4 in 1992 and 1998 while summer HT days in south-central region were 64.4 and 45.5 days respectively and these were 58.6 and 51.8 days respectively for south region. The correlation analysis suggests that Nino 3.4 index of preceding months, for example, FMA can be used as an indicator of summer hot days over southern India.

\section{Conclusions and discussion}

Global warming plays a key role in the variation in temperature extremes and a recent evaluation by IPCC has reported an acceleration of warming, which is mainly caused by the effect of greenhouse gases (IPCC 2013). There has been an increase in the maximum temperature during the last century over India as well (Dash et al. 2007). Therefore, it is necessary to understand the climatology and longterm trends of summer high temperature days in India. In this study, we have examined the statistics and behaviour of summer HT days over India using data from 176 surface meteorological stations for the period 1969-2013. On long-term basis (19692013), the summer HT days have increased in north $(3 \%)$, west $(5 \%)$ and south $(18 \%)$ and decreased in north-central (4\%) and east (9\%). The data analysis reveals main regions of large number of HT days in west, north-central, and south-central regions of the country where most of the stations have higher long-term mean summer HT days $(>80$ days) and lower standard deviation ( $<15$ days). This may be due to the fact that these regions are at low elevation and semi-arid to arid situated adjacent to the great Thar Desert of India from where dry and hot winds blow. The variability in the number of summer HT days is large in east and south regions, especially over Gangetic West Bengal, Orissa and Tamil Nadu suggesting these regions are prone to sporadic extreme hot summer years. With massive urbanisation, mega cities in India are prone to rapid unplanned growth and increase in human population. As population grows in cities, concerns are raised about the warming caused by quick urbanization and modification of land surfaces. Climate conditions such as consecutive warm days can have important impacts on human society, economy, and environment. 
The trend analysis shows that there has been an overall increase in the number of HT days across India, while this increase happened mainly in the latter half of the study period. In the first half of the study period (1969 to 1990), a decrease in the number of HT days was recorded in most of north $(3 \%)$, west $(6 \%)$, north-central $(6 \%)$, east $(5 \%)$, and south-central (8\%) while it has increased by $13 \%$ in south region. However, during the second half (1991-2013), summer HT days have increased by $5 \%$ in north, $6 \%$ in west, $1 \%$ in north-central and $2 \%$ in south region. Therefore, it is evident that the latter period (1991-2013) has experienced sudden increase in summer HT days over north, west and north-central regions and along eastern coast of India, with the shift occurring in the mid to late 1990s. Similar results have been reported by Dash et al. (2007) for states like Orissa and Andhra Pradesh on the east coast of India. The increasing trends in summer hot days over India during the period of study corroborates well with the projections given by IPCC (2007) and potential future assessment of changes in climate extremes given by Tebaldi et al. (2006). Our study has also revealed that the frequency of higher HT days is spatially as well as temporally different in different regions of the country. High temperature spells occur when a system of high atmospheric pressure moves into an area where air from upper levels of atmosphere is pulled down leading to cloud free sky resulting in increase in temperature. The combination of all these factors come together to create the exceptionally long spells of hot temperatures. These hot spells are moderated by pre-monsoon thundershowers and rapid northward progress of monsoon. For example, during 2013 (coolest year) there were regular pre-monsoon thundershowers in west and central parts of India. Furthermore, while the monsoon onset was on time (1 June, 2013), its advance was very rapid as it covered whole country by 16 June, 2013 thereby reducing HT days both temporally and spatially. On the other hand, in 2010 (warmest year) monsoon onset was on 31 May but it remained stagnant mid-way over north Maharashtra till 4 July, 2010 and covered entire India on 6 July, 2010 resulting in more hot days over large parts of north, west, and central India.

Effects of climate change will lead to more and more hot days than cold days as given by IPCC in a recent report (IPCC 2013). Changes in high temperature extremes will lead to significant increase of heat exposure during the summer season in most parts of India. Years of higher temperature days can cause massive deaths from hyperthermia, large scale crop failures, and shortages of water resources and power supplies (Haines et al. 2006; McMichael et al. 2006). High temperature days are also regarded as the most prominent cause of weather-related human mortality in the USA (Luber and McGeehin 2008) and such events have the most obvious effect on infectious diseases. It is extremely likely that human influence has been the dominant cause of the observed warming since the mid-20th century (IPCC 2013). The results of this study will help general public as well as administrators to recognize the risk to society from high temperature events in India.

Following are the main conclusions of this study:

- Summer high temperature days are having longterm decreasing trends in north-central and east regions and increasing trends in west, southcentral and south regions of India during 19692013.

- Highest maximum temperature trends in summer season during 1969-2013 are significantly increasing in all regions of India except over east where it is significantly decreasing.

- Out of 25 selected mega cities, 16 are showing long-term (1969-2013) increasing trends in summer high temperature days, which are significant at Kolkata $(+2.73$ days per decade), Chennai $(+2.96$ days per decade), Jaipur $(+2.91$ days per decade), Visakhapatnam ( +4.59 days per decade), Madurai ( +4.57 days per decade), and Rajkot (+2.36 days per decade).

- Striking feature of the trend analysis of mega cities is the sharp increase in summer high temperature days during the recent period of 1991-2013 in highly populated cities of Mumbai $(+2.16$ days per decade), New Delhi $(+6.3$ days per decade), Chennai ( +7.96 days per decade) along with Jaipur (+7.73 days per decade), and Visakhapatnam (+18.14 days per decade).

- By splitting study period (1969-2013) in two halves (1969-1990 and 1991-2013), we have found contrasting features of trends in high temperature days supporting summer warming over north, west, north-central regions, and east coast of India during the latter half (1991-2013), suggesting abrupt change in numbers of HT days probably in mid 1990s.

- The analysis of high temperature days shows occurrence of the warmest summer in 2010 and the coolest summer in 2013 during the period of study. Further, there were 15 warm summer years in India during this period out of which 8 occurred in the last decade $(2010,2012,2009$, 2004, 2003, 2002, 2007 and 2005). Also there were 8 cool summer years $(2013,1990,1989,1971$, 2001, 1978, 2008 and 1997).

- Summer hot days over southern India indicates significant positive correlation with Nino 3.4 index. 


\section{Acknowledgements}

Authors are grateful to Dr L S Rathore, Director General of Meteorology for the encouragement and support. They are also thankful to the unknown reviewers for the constructive suggestions that helped to improve the manuscript.

\section{References}

Aguilar E, Peterson T C, Ram'irez Obando P, Frutos R, Retana J A, Solera M, Gonz'alez Santos I, Araujo R M, Rosa Santos A, Valle V E, Brunet India M, Aguilar L, A'lvarez L, Bautista M, Castanõ'n C, Herrera L, Ruano R, Siani J J, Obed F, Hern'andez Oviedo G I, Salgado J E, V'asquez J L, Baca M, Guti'errez M, Centella C, Espinosa J, Mart'inez D, Olmedo B, Ojeda Espinoza C E, Haylock M, N'unez R, Benavides $\mathrm{H}$ and Mayorga $\mathrm{R} 2005$ Changes in precipitation and temperature extremes in central America and northern South America 1961-2003; J. Geophy. Res. Atmos. 110 D23107, doi: 10.1029/2005JD006119.

Alexander L V, Zhang X, Peterson T C, Caesar J, Gleason B, Klein Tank A M G, Haylock M, Collins D, Trewin B, Rahimzadeh F, Tagipour A, Ambenje P, Rupa Kumar K, Revadekar J and Griffiths G 2006 Global observed changes in daily climate extremes of temperature and precipitation; J. Geophys. Res. Atmos. 111 D05109, doi: 10.1029/2005JD006290.

Arora M, Goel N K and Pratap Singh 2005 Evaluation of temperature trends over India; Hydrol. Sci. J. 50 81-93.

Bartolini G, Morabito M, Crisci A, Grifoni D, Torrigiani T, Petralli M, Maracchi G and Orlandini S 2008 Recent trends in Tuscany (Italy) summer temperature and indices of extremes; Int. J. Climatol. 28 1751-1760, doi: 10.1002/joc.1673.

Chaudhury S K, Gore J M and Sinha Ray K C 2000 Impact of heat waves over India; Curr. Sci. 79(2) $153-155$.

De U S 2001 Climate change impact: Regional scenario; Mausam 52 201-212.

De U S, Dube R K and Prakasa Rao G S 2005 Extreme weather events over India in the last 100 years; J. Indian Geophys. Union 9(3) 173-187.

DeGaetano A T and Allen R J 2002 Trends in twentiethcentury temperature extremes across the United States; J. Clim. 15(22) 3188-3205.

Dash S K, Jenamani R K, Kalsi S R and Panda S K 2007 Some evidence of climate change in twentieth-century India; Climatic Change 85 299-321.

Easterling D R, Horton B, Jones P D, Peterson T C, Karl T R, Parker D E, Salinger M J, Razuvayev V, Plummer N, Jamason P and Folland C K 1997 Maximum and minimum temperature trends for the globe; Science $277364-367$.

Easterling D R, Meehl G A, Parmesan C, Changnon S A, Karl T R and Mearns L O 2000 Climate extremes: Observations, modeling, and impacts; Science 289(5487) 2068-2074, doi: 10.1126/science.289.5487.2068.

Frich P, Alexander L V, Della-Marta P, Gleason B, Haylock M, Klein Tank A M G and Peterson T 2002 Observed coherent changes in climatic extremes during the second half of the 20th century; Clim. Res. 19 193-212.

Gaffen D J and Ross R J 1998 Increased summertime heat stress in the US; Nature 36 529-530.
Griffiths G M, Chambers L E, Haylock M R, Manton M J, Nicholls N, Baek H-J, Choi Y, Della-Marta P M, Gosai A, Iga N, Lata R, Laurent V, Maitrepierre L, Nakamigawa H, Ouprasitwong N, Solofa D, Tahani L, Thuy D T, Tibig L, Trewin B, Vediapan K and Zhai P 2005 Change in mean temperature as a predictor of extreme temperature change in the Asia-Pacific region; Int. J. Climatol. 25 1301-1330, doi: 10.1002/joc.1194.

Haines A, Kovats R S, Campbell-Lendrum D and Corvalan C 2006 Climate change and human health: Impacts, vulnerability, and mitigation; The Lancet 367 2101-2109.

Hingane L S, Rupa Kumar K and Murty V R 1985 Longterm trends of surface air temperature in India; Int. J. Climatol. 5 521-528.

IPCC 2007 Climate change 2007-The physical science basis; Contribution of working group I to the fourth assessment report of the IPCC; Cambridge University Press, Cambridge,United Kingdom.

IPCC 2013 Climate Change 2013 - The physical science basis; Intergovernmental Panel on Climate Change; https://www.ipcc.ch/report/ar5/wg1.

Karl T R and Easterling D R 1999 Climate extremes: Selected review and future research directions; Clim. Change 42 309-325.

Klein Tank A M G, Peterson T C, Quadir D A, Dorji S, Zou X, Tang H, Santhosh K, Joshi U R, Jaswal A K, Kolli R K, Sikder A, Deshpande N R, Revadekar J V, Yeleuova K, Vandasheva S, Faleyeva M, Gomboluudev P, Budhathoki K P, Hussain A, Afzaal M, Chandrapala L, Anvar H, Amanmurad D, Asanova V S, Jones P D, New M G and Spektorman T 2006 Changes in daily temperature and precipitation extremes in central and south Asia; J. Geophys. Res. 111 D16105, doi: 10.1029/2005JD006316.

Kothawale D R and Rupa Kumar K 2005 On the recent changes in surface temperature trends over India; Geophys. Res. Lett. 32 L18714, doi: 10.1029/2005GL023528.

Kothawale D R, Munot A A and Krishna Kumar K 2010a Surface air temperature variability over India during 1901-2007 and its association with ENSO; Clim. Res. 42 89-104.

Kothawale D R, Revadekar J V and Rupa Kumar K 2010b Recent trends in pre-monsoon daily temperature extremes over India; J. Earth Syst. Sci. 119 51-65.

Luber G and McGeehin M 2008 Climate change and extreme heat events; Am. J. Prev. Med. 35(5) 429435.

Manton M J, Della-Marta P M, Haylock M R, Hennessy K J, Nicholls N, Chambers L E, Collins D A, Daw G, Finet A, Gunawan D, Inape K, Isobe H, Kestin T S, Lefale P, Leyu C H, Lwin T, Maitrepierre L, Ouprasitwong N, Page C M, Pahalad J, Plummer N, Salinger M J, Suppiah R, Tran V L, Trewin B, Tibig I and Yee D 2001 Trends in extreme daily rainfall and temperature in southeast Asia and the south Pacific: 1916-1998; Int. J. Climatol. 21269 284.

McMichael A J, Woodruff R E and Hales S 2006 Climate change and human health: Present and future risks; The Lancet 367(9513) 859-869.

Natarajan K K 1964 A note on the hot days of Madras (1875-1963); Ind. J. Meteorol. Geophys. 14 431-436.

New M, Hewitson B, Stephenson D B, Tsiga A, Kruger A, Manhique A, Gomez B, Coelho C A S, Masisi D N, Kululanga E, Mbambalala E, Adesina F, Saleh H, Kanyanga J, Adosi J, Bulane L, Fortunata L, Mdoka M L and Lajoie R 2006 Evidence of trends in daily climate extremes over southern and west Africa; J. Geophys. Res. Atmos. 111 D14102, doi: 10.1029/2005JD006289.

Pai D S, Thapliyal V and Kokate P D 2004 Decadal variation in the heat and cold waves over India during 1971-2000; Mausam 55(2) 281-292. 
Pai D S, Nair S A and Ramanathan A N 2013 Long term climatology and trends of heat waves over India during the recent 50 years (1961-2010); Mausam 64(4) 585-604.

Pal I and Al-Tabbaa A 2010 Long-term changes and variability of monthly extreme temperatures in India; Theor. Appl. Climatol. 100 45-56.

Peterson T C, Taylor M A, Demeritte R, Duncombe D L, Burton S, Thompson F, Porter A, Mercedes M, Villegas E, Fils R S, Klein Tank A, Martis A, Warner R, Joyette A, Mills W, Alexander L and Gleason B 2002 Recent changes in climate extremes in the Caribbean region; J. Geophys. Res. Atmos. 107 4601, doi: 10.1029/2002JD002251.

Qian W and Qin A 2006 Spatial-temporal characteristics of temperature variation in China; Meteor. Atmos. Phys. 93 $1-16$.

Raghavan K 1966 Climatology of severe cold waves in India; Ind. J. Meteorol. Geophys. 18(1) 91-96.

Rao G S P, Krishna Murty M and Joshi U R 2005 Climate change over India as revealed by critical extreme temperature analysis; Mausam 56 601-608.

Ray K, Chincholikar J R and Mohanty M 2013 Analysis of extreme high temperature conditions over Gujarat; Mausam 64(3) 467-474.

Revadekar J V, Kothawale D R, Patwardhan S K, Pant G B and Rupakumar K 2012 About the observed and future changes in temperature extremes over India; Nat. Hazards 60(3) 1133-1155.

Rupa Kumar K, Krishankumar K and Pant G B 1994 Diurnal asymmetry of surface temperature trends over India; Geophys. Res. Lett. 21 677-680.

Sinha Ray K C and De U S 2003 Climate change in India as evidenced from instrumental records; WMO Bull. $\mathbf{5 2}$ 53-59.

Srivastava H N, Dewan B N, Dikshit S K, Rao P G S, Singh S S and Rao K R 1992 Decadal trends in climate over India; Mausam 43 7-20.

Subbaramayya I and Surya Rao D A 1976 Heat wave and cold wave days in different states of India; Ind. J. Meteorol. Hydrol. Geophys. 27 436-440.
Tebaldi C, Hayhoe K, Arblater J M and Meehl G A 2006 Going to the extremes: An intercomparison of modelsimulated historical and future changes in extreme events; Clim. Change 79 185-211, doi: 10.1007/s10584-006-9051-4.

Vincent L A, Peterson T C, Barros V R, Marino M B, Rusticucci M, Carrasco G, Ramirez E, Alves L M, Ambrizzi T, Berlato M A, Grimm A M, Marengo J A, Molion L, Moncunill D F, Rebello E, Anunciacao Y M T, Quintana J, Santos J L, Baez J, Coronel G, Garcia J, Trebejo I, Bidegain M, Haylock M R and Karoly D 2005 Observed trends in indices of daily temperature extremes in South America 1960-2000; J. Climate 18 5011-5023.

Wei K and Chen W 2009 Climatology and trends of high temperature extremes across China in summer; Atmos. Oceanic Sci. Lett. 2 153-158.

Yan Z, Jones P D, Davies T D, Moberg A, Bergstrom H, Camuffo D, Cocheo C, Maugeri M, Demaree G, Verhoeve T, Thoen E, Barriendos M, Rodriguez R, Martin-vide J and Yang C 2002 Trends of extreme temperatures in Europe and China based on daily observations; Clim. Change 53 355-392.

You Q, Kang S, Aguilar E and Yan Y 2008 Changes in daily climate extremes in the eastern and central Tibetan Plateau during 1961 to 2005; J. Geophys. Res. 113 D07101, doi: 10.1029/2007JD009389.

Zhai P and Pan X 2003 Trends in temperature extremes during 1951-1999 in China; Geophys. Res. Lett. 30 1913, doi: 1910.1029/2003GL018004.

Zhang X, Vincent L, Hogg W and Niitsoo A 2000 Temperature and precipitation trends in Canada during the 20th century; Atmos. Ocean 38 395-429.

Zhang X, Aguilar E, Sensoy S, Melkonyan H, Tagiyeva U, Ahmed N, Kutaladze N, Rahimzadeh F, Taghipour A, Hantosh T H, Alpert P, Semawi M, Ali M K, Al-Shabibi M H S, Al-Oulan Z, Zatari T, Al Dean Khelet I, Hamoud S, Sagir R, Demircan M, Eken M, Adiguzel M, Alexander L, Peterson T C and Wallis T 2005 Trends in Middle East climate extreme indices from 1950 to 2003; J. Geophys. Res. Atmos. 110 D22104, doi: 10.1029/2005JD006181. 